\title{
Biomimetic Strategies for Engineering Composite Tissues
}

\author{
Nancy M. Lee ${ }^{1}$, Jennifer L. Robinson ${ }^{1,2}$, and Helen H. Lu ${ }^{1,3}$
}

1. Biomaterials and Interface Tissue Engineering Laboratory

Department of Biomedical Engineering

Columbia University

New York, NY 10027

2. Division of Orthodontics, College of Dental Medicine

Columbia University

New York, NY 10032

3. To whom all correspondence should be addressed:

Helen H. Lu, Ph.D.

Department of Biomedical Engineering

Columbia University

1210 Amsterdam Avenue

351 Engineering Terrace, MC 8904

New York, NY 10027

212-854-4071 (office), 212-854-8725 (fax)

hhlu@columbia.edu 


\begin{abstract}
The formation of multiple tissue types and their integration into composite tissue units presents a frontier challenge in regenerative engineering. Tissue-tissue synchrony is crucial in providing structural support for internal organs and enabling daily activities. This review highlights the state-of-the-art in composite tissue scaffold design, and explores how biomimicry can be strategically applied to avoid over-engineering the scaffold. Given the complexity of biological tissues, determining the most relevant parameters for recapitulating native structurefunction relationships through strategic biomimicry will reduce the burden for clinical translation. It is anticipated that these exciting efforts in composite tissue engineering will enable integrative and functional repair of common soft tissue injuries and lay the foundation for total joint or limb regeneration.
\end{abstract}

Keywords: scaffolds, interface, tissue engineering, composite tissues, strategic biomimicry 


\section{Introduction}

The prevalence of trauma and disease resulting in the loss or failure of tissue and organ function has engendered a clinical need for the development of strategies to repair and regenerate damaged tissues. Combining 3D scaffolds, cells, and bioactive cues, tissue engineering principles[1;2] have led to the formation of a variety of single-tissue systems in vitro and in vivo, elucidating foundational design rules for tissue regeneration. Biological tissues and organs are inherently composites in nature, with multiple tissue types and cell populations interfacing with each other and acting in synchrony to enable complex biological functions. Therefore, the next horizon in the field of tissue regeneration moves to join these single-tissue systems into composite tissue units and integrate these composite tissue grafts to reestablish biological function in vivo.

Synchronized tissue units are especially important in the musculoskeletal system, whereby physiological motion is orchestrated through concerted actions of bone in conjunction with a variety of soft tissues. The tissue-tissue junctions through which they integrate are characterized by multiple matrix regions that exhibit spatial changes in cell phenotype, matrix composition, and organization that manifest into region-specific mechanical properties (Fig. 1). Unfortunately, these connective junctions are also prone to injury and degeneration, and fail to regenerate following standard surgical repair methods. For example, current repair methods for anterior cruciate ligament $(A C L)$ injuries and rotator cuff tendon tears often result in disorganized tissue that is compositionally and structurally inferior to native tissue, leading to poor long-term outcomes and high failure rates.[3] Similarly, cartilage treatment options for conditions such as osteoarthritis, are limited by poor graft integration with the underlying bone and host cartilage.[4] The overall shortcoming of conventional treatment options for soft tissue injuries is the lack of focus on tissue integration to restore function. Thus, it is necessary to design and engineer grafts with properties that reflect the tissue structure and resulting function. 
While a number of approaches to musculoskeletal soft tissue regeneration have been explored with promising results,[5-8] successful clinical translation of these grafts will depend largely on their ability to achieve functional and extended integration with the surrounding host tissue. Each tissue phase exhibits distinct cellular populations and unique matrix composition and organization, yet must operate in unison with adjoining tissues to facilitate physiological function and maintain tissue homeostasis. Inspired by these multi-tissue structures, a variety of complex scaffold designs have been developed to recapitulate the native spatial and compositional inhomogeneity.[9-11] This review will discuss current regenerative engineering efforts in ligament-bone, tendon-bone, and cartilage-bone integration, with a focus on biomaterial- and cell-based strategies for engineering biomimetic, functional, and spatial variations in composition and mechanical properties. Furthermore, scaffolds engineered with stratified and gradient properties will be highlighted, as both designs offer significant promise for composite tissue engineering. Gradient designs allow for a gradual and continuous transition in composition and properties, while stratified scaffolds consist of compositionally distinct phases which are physically contiguous with each other. The former seeks to mimic known gradients observed across different types of tissue while the latter is easier to fabricate presently at physiologically relevant scales, and simulates these changes via step functions. In light of the complexity of multi-tissue regeneration, the application of strategic biomimicry across tissuetissue junctions, or prioritizing the most crucial properties of native tissue necessary to recapitulate function, is essential to avoid over-engineering the scaffold design. Therefore, this review will also highlight these strategic design approaches to develop both stratified and gradient scaffolds for ligament, tendon, and cartilage regeneration and conclude with a summary and reflections on future directions in composite tissue engineering.

\section{Composite Grafts for Ligament Regeneration}


There are over 800 ligaments in the body, functioning to support internal organs and connect bone to bone. Ligaments are anchored to bone through either an indirect insertion as found in the periodontal ligament (PDL) of the tooth or through direct insertions as present in the ACL.[12] In the indirect insertion, collagen fibers attach to bone,[13] whereas in the direct insertion, a layer of fibrocartilage serves as a transition matrix from soft tissue to bone. This interfacial layer of fibrocartilage is subdivided into mineralized and non-mineralized regions. Regeneration of these complex transitions will require the formation of composite tissue units of bone-ligament or bone-ligament-bone (indirect insertions), and bone-interface-ligamentinterface-bone (direct insertions).

A classic example of the indirect insertion can be found in the periodontium of the tooth. It consists of multiple periodontal ligament (PDL) fibers connecting the tooth root cementum with alveolar bone. The collagenous PDL insertions are characterized by Sharpey's Fibers that anchor the tooth to the jaw and withstand masticatory forces. Structural and compositional cues, growth factors, and relevant cell types have been used to coordinate the regeneration of this complex tissue. Recently, Costa et al. designed a stratified, bi-phasic bone-ligament scaffold[14], whereby a poly(caprolactone)- $\beta$-tricalcium phosphate (PCL- $\beta$-TCP) fiber scaffold for bone regeneration was heat-fused to an electrospun PCL scaffold for the ligament region. When implanted subcutaneously in athymic rats, enhanced bone formation and vascular infiltration attributed to the large diameter fibers in the PDL phase were observed after 8 weeks. Similarly, solid free-form fabrication methods and 3D printing allow for precise regional control of scaffold architecture, and have been utilized for engineering composite tissues mimicking the periodontium. For example, Park et al. designed a bone-ligament scaffold consisting of perpendicular PDL channels fabricated from poly(glycolic acid) (PGA) fused to a porous PCL bone region. By using micro-CT to image the defect, scaffolds could be specifically designed to anatomically fit defects.[15-17] Cell-seeded constructs were evaluated in surgically created 
periodontal defects in athymic rats. An oriented fiber interface that promoted greater tissue infiltration was observed at week 6 , while such an organized transition was absent in scaffolds with a random architecture. Combining physical and chemical cues, Lee et al. developed a 3D printed, multi-phased PCL-hydroxyapatite (HA), bone-ligament-bone, scaffold with phasespecific microchannel geometry for dentin/cementum, PDL, and alveolar bone.[18] Spatiotemporal growth factor release was achieved via incorporation of growth factors encapsulated in poly(lactic-co-glycolic acid) (PLGA) microspheres within relevant tissue regions. Additionally, seeding with dental pulp stem/progenitor cells yielded aligned PDL-like collagen fibers that inserted into bone-like tissue after 6 weeks of subcutaneous implantation in immunodeficient mice.

Similarly for direct insertions, which are found in key ligaments such as the ACL, recent work has shifted from the focus on the ligament proper towards multi-tissue designs consisting of bone-ligament-bone, ligament-bone or ligament-interface-bone regions. A challenge in the implementation of bone-ligament-bone designs, however, is the regeneration of a fibrocartilaginous interface. The fibrocartilage interface is optimized to withstand a combination of tensile and compressive loading and mediate load transfer at the ligament-bone junction.[1923] Therefore, incorporating interface regeneration into graft design will be essential for achieving physiological joint function after ligament reconstruction. To this end, Spalazzi et al. reported on a stratified ligament-interface-bone scaffold,[24;25] consisting of a PLGA electrospun mesh for ligament, sintered PLGA microspheres for interface, and sintered PLGA$45 \mathrm{~S} 5$ bioactive glass (BG) for bone. Tri-culture of fibroblasts, chondrocytes, and osteoblasts resulted in region-specific matrix synthesis, and matrix interconnectivity between phases. Building on these findings, Subramony et al. developed a five-phased, nanofiber-based scaffold for ACL repair.[26] In this bone-interface-ligament-interface-bone design, a PCL-based scaffold was fabricated, and mechanoactive collars were applied at the ligament-bone junctions. In vivo evaluation showed enhanced formation of mineralized tissue within the bone tunnels, as well as 
superior mechanical properties compared to single-phased controls. Using a cell based approach, Wang et al. seeded decellularized rabbit tendons with osteoblasts and chondrocytes genetically modified for overexpression of RUNX2 (bone marker) and SOX9 (cartilage marker), respectively.[27] The integrated neotissue on this ligament-interface-bone scaffold displayed a gradient in matrix properties as confirmed via histology and immunohistochemistry. These studies demonstrate the successful use of stratified scaffolds, engineered with phase-specific biomimetic cues, to promote phase-specific matrix regeneration including the fibrocartilaginous transition.

Gradient scaffold designs are another promising approach for interface tissue engineering, exhibiting the potential to recapture and pre-design the micro- and nano-scale organization of native tissue transitions. Gradients in mineral distribution[28] as well as fiber composition[29;30] and alignment have been achieved[31] via viral coating and electrospinning methods, respectively. The next step is to engineer these gradients at physiologically relevant scales (Table 1).

The innovative composite tissue engineering approaches highlighted here reaffirm that integration of soft tissue to the native bone remains a primary challenge in functional ligament tissue engineering (Table 2). These studies demonstrate the use of strategic biomimicry for the design of multi-tissue scaffolds towards this end. Incorporating interface regeneration into the graft design is essential towards the reestablishment of both indirect (fibrous) and direct (fibrocartilaginous) insertions, which is critical towards achieving physiological function.

\section{Composite Grafts for Tendon Regeneration}

The tendon, which joins muscle to bone, is comprised of structurally contiguous yet compositionally distinct regions of muscle-interface-tendon-interface-bone. The rotator cuff tendon is one of the most commonly injured tendons. Clinical repair procedures typically involve tendon reattachment to bone by mechanical means. However, tendon detachment 
remains the primary cause of surgical failure, as the restoration of the native tendon-bone insertion is not adequately achieved. Like the ACL, tendons insert into subchondral bone through a fibrocartilage transition.[21;22;32] Focusing on this fibrocartilaginous interface, Moffat et al. designed a biphasic interface scaffold consisting of contiguous layers of aligned PLGA and PLGA-HA nanofibers joined via electrospinning, which are intended to mimic the non-calcified and calcified fibrocartilage regions, respectively.[33] The scaffold was used as an inlay between tendon and bone and evaluated in rodent[33] and ovine[34] rotator cuff repair models. The formation of a fibrocartilage-like matrix on both scaffold phases was observed, with the mineral phase of the scaffold guiding the formation of calcified fibrocartilage. Pre-seeding the biphasic scaffold with bone marrow-derived cells promoted fibrocartilage matrix maturation and enhanced collagen organization at the tendon-bone junction.

Gradient scaffold designs, with a continuous transition from soft to hard tissue, have also been explored for tendon-bone integration. Several groups have sought to pre-engineer the mineral gradient[35] at the tendon-bone junction by employing controlled soaking in a calcium phosphate solution or soaking bone tissue in a demineralizing solution. Achieving a physiologically relevant (Table 1) gradient in mineral, however, has been challenging, as these methods have yielded gradients that span millimeters[36;37] to centimeters.[38]

Critical to the regeneration of the tendon-bone interface is the reestablishment of the fibrocartilage transition between the soft and hard tissues. Guided by the principle of strategic biomimicry, the tendon scaffold should incorporate structural and compositional heterogeneity, notably through the inclusion of mineral. As demonstrated in the studies presented, these qualities enable phase-specific mechanical properties as well as support multiple cell populations (Table 3). The use of appropriate animal and injury models also needs to be considered to ensure that the scaffold is evaluated in a physiologically relevant environment.

\section{Composite Grafts for Cartilage Regeneration}


Similar to ligaments and tendons, articular cartilage health and function is intimately tied to the subchondral bone.[39] Structurally, the two tissue types are connected via the osteochondral interface, which consists of a calcified cartilage barrier with a modulus intermediate between articular cartilage and bone[40] that is instrumental for load bearing and force distribution across these tissues.[41-43] Thus, in addition to meeting the complex mechanical demands of articulation, the ideal cartilage scaffold must also enable cartilage-bone integration by connecting these two tissues through a stable and physiologically-relevant calcified cartilage interface.

Initial work on osteochondral regeneration focused solely on the cartilage and bone as separate units. The significance of the osteochondral interface was demonstrated by Hunziker et al.[44] By placing a membrane between cartilage and bone compartments, vascular ingrowth from the subchondral bed was limited, preventing ectopic mineralization and preserving newly formed cartilage. As such, many stratified systems have been developed to promote the repair of an interfacial region based on scaffold chemistry and mechanical properties. Holmes and colleagues aimed to enhance the repair process by stimulating growth via a cartilage-bone scaffold pore architecture and geometry utilizing 3D printed PLA biphasic constructs.[45] Following rational design and incorporating interlocking structures within the printed scaffolds, the compressive modulus and shear strength at the interface were enhanced. Further, Jiang et al. developed a stratified scaffold (cartilage-interface-bone) consisting of a hydrogel-based region for cartilage regeneration, a hybrid hydrogel and polymer-ceramic composite microsphere region for interface regeneration, and a polymer-ceramic composite microsphere region for bone regeneration.[46;47] Chondrocyte and osteoblast co-culture on this scaffold system resulted in the formation of distinct yet continuous cartilaginous and osseous matrices, as well as a calcified interfacial region largely due to the pre-engineered mineralized scaffold phase. 
Cell-based approaches for cartilage-bone integration were pioneered by Kandel et al., who identified deep zone chondrocytes (DZC) as a cell source capable of producing mineralized matrix if given appropriate cues.[48;49] Building on this work, Khanarian et al. evaluated both degradable (alginate)[50] and non-degradable (agarose)[51] hydrogel-mineral composite scaffolds seeded with DZC for calcified cartilage formation. Both scaffold systems were found to promote formation of all layers of the cartilage including a calcified cartilage layer. Recently, Mellor et al. utilized calcium ion concentrations as a differentiation gradient to spatially promote chondrogenesis and osteogenesis in human adipose-derived stem cells in PLA-TCP multilayered electrospun meshes.[52] Immunohistochemical staining and gene expression revealed promotion of distinct cartilage and bone regeneration within the construct. However, the formation of an intermediate, mineralized layer was not discussed.

Given the mineral transition which physiologically occurs across the osteochondral interface, gradient scaffolds have also been investigated for integrative cartilage repair. AvivGavriel et al. fabricated mineral-gradient membranes by exposing thin gelatin gels containing either calcium or phosphate ions to a solution of the complementary ion.[53] This resulted in the formation of a partially-calcified hydrogel membrane which can be adapted for integration of a cartilage graft with bone. Combining elements of both stratified and gradient designs, Harley et al. fabricated layered collagen-GAG scaffolds consisting of distinct cartilage and bone regions connected by a continuous interface via liquid-phase co-synthesis.[54] This unique method of fabrication resulted in small gradients of dissimilar materials extending across a soft interface. In vivo evaluation of the acellular scaffold in a caprine model revealed that this design supported significant formation of both cartilaginous and osseous tissue on the respective phases.[55] While both of these methods produce scaffolds with a gradient of mineral composition in transitioning from soft to hard tissue, it is unclear whether these methods result in calcified cartilage thicknesses that match physiological levels (Table 1).[56] 
The studies collectively demonstrate the successful use of strategic biomimicry to fabricate composite scaffold designs in both stratified and gradient form to engineer cartilageinterface or cartilage-interface-bone grafts (Table 4). It is evident from these studies that the presentation of physiological mineral chemistry and composition to cells primed to produce calcified matrix in a scaffold that cells can remodel are key factors in promoting a mineralized cartilage interface between cartilage and bone. While the presentation of growth factors in a gradient system shows significant promise,[57] the spatiotemporal release and diffusion kinetics must be addressed to reduce any undesired side effects to the surrounding tissue. Further, the success of these tissue regeneration approaches will depend on defect site and animal model used for evaluation.

\section{Summary and Future Directions}

An overview of current concepts in engineering composite tissues for soft and hard tissue repair has been presented here. These biomimetic scaffold designs seek to recapitulate the spatial distribution in compositional, structural, and mechanical properties inherent between hard and soft tissues. Collectively, they delineated several strategies that highlight the value and importance of strategic biomimicry in designing therapies for multi-tissue regeneration. First, one-tissue centric, single-phased scaffold systems are insufficient for recapitulating soft tissue functionality due to poor graft integration with host tissues. Next, regional scaffold cues can be used to direct cell fate in the absence of differentiation media both in vitro and in vivo. Specifically, strategic patterning of relevant key factors has been shown to exercise spatial control in stem cell differentiation on stratified and gradient scaffolds in which all regions are bathed in a common media.[38;58-62] Therefore, from a strategic biomimicry standpoint, it is likely that spatial control of cell distribution and relevant inductive agents on the stratified or gradient scaffold is required to control the fate of each cell population and direct region-specific matrix elaboration. 
Despite the exciting advancements in scaffold design and fabrication made in a relatively short period, there remain a number of challenges in this fast-growing field. One common discussion point is whether to use stratified or gradient scaffold designs. While gradient scaffolds exhibit a gradual and continuous transition in composition and mechanical properties, the stepwise increase in mineral content, characteristic of stratified scaffolds, better approximates the exponential increase in mineral content across the interface regions.[63] On the other hand, a sharp transition between dissimilar materials is inherently weaker than a gradual interface of interdigitated phases.[64;65] One strategy to circumvent this is to design all of the stratified scaffold phases with predominately the same type of biomaterial, preventing delamination and ensuring structural continuity.[24;25] Thus from a strategic biomimicry standpoint, a systematic comparison of gradient scaffolds with stratified designs is required to determine whether either or both are optimal for multi-tissue formation.

Another major challenge is engineering scaffolds for multi-tissue regeneration that are on a physiologically relevant scale (Table 1). While the gradient scaffolds nicely produce a smooth transition in properties, these alterations in properties do not match the scale of native transitions. Fortunately, due to gained interest and technological advancements, fabrication of multi-tissue scaffolds with transition of properties at physiologically relevant scale is attainable in the next decade. Another technical challenge in ex vivo engineering of complex tissues resides in how to devise an optimal culturing media or loading regimen that ensures the phenotypic maintenance of multiple cell populations and the elaboration of related matrix. For example, Wang et al. investigated the effects of ascorbic acid and $\beta$-glycerophosphate dose on human osteoblasts and ligament fibroblasts, and devised a co-culture media which maintained osteoblast function without inducing unwanted mineralization by fibroblasts.[66] To this end, the mechanistic effects of biological, chemical, and physical stimuli must be thoroughly evaluated to enable more refined and targeted scaffold design and graft fixation. 
The strategic biomimicry approach emphasized here, where scaffolds can be designed to recapitulate the key compositional and structural organization properties of the native interface, will be instrumental for reestablishment of integrated musculoskeletal tissue systems with restored physiological function. It is anticipated that these efforts will lead to the development of the next generation of functional fixation devices for orthopaedic repair, as well as augment the potential for clinical translation of tissue-engineered orthopaedic grafts. Moreover, by bridging distinct types of tissues, interface tissue engineering will be instrumental towards engineering complex organs and total limb or joint regeneration.

\section{Acknowledgements}

This work was supported by the National Institutes of Health (R21-AR056459, R01-AR055280), the New York State Stem Cell ESSC Board (NYSTEM C029551) and the DoD CDMRP award (W81XWH-15-1-0685).

\section{References}

1. Skalak R: Tissue engineering: proceedings of a workshop, held at Granlibakken, Lake Tahoe, California, February 26-29, 1988. Edited by Skalak R, Fox CF. New York, NY: Liss; 1988.

2. Langer R, Vacanti JP: Tissue engineering. Science 1993, 260:920-926.

3. Galatz LM, Ball CM, Teefey SA, Middleton WD, Yamaguchi K: The outcome and repair integrity of completely arthroscopically repaired large and massive rotator cuff tears. J.Bone Joint Surg.Am. 2004, 86-A:219-224.

4. Hunziker EB: Articular cartilage repair: basic science and clinical progress. A review of the current status and prospects. Osteoarthr.Cartilage 2002, 10:432-463.

5. Laurencin C.T., Ambrosio AA, Borden M, Cooper JA: Tissue Engineering: Orthopedic Applications. In Annual Review of Biomedical Engineering. Edited by Yarmush ML, Diller KR, Toner M. 1999:19-46.

6. Hutmacher DW: Scaffolds in tissue engineering bone and cartilage. Biomaterials 2000, 21:2529-2543. 
7. Temenoff JS, Mikos AG: Review: tissue engineering for regeneration of articular cartilage. Biomaterials 2000, 21:431-440.

8. Vunjak-Novakovic G, Altman G, Horan R, Kaplan DL: Tissue engineering of ligaments. Annu.Rev.Biomed.Eng 2004, 6:131-156.

9. Mikos AG, Herring SW, Ochareon P, Elisseeff J, Lu HH, Kandel R, Schoen FJ, Toner M, Mooney D, Atala A, Dyke ME, Kaplan D, Vunjak-Novakovic G: Engineering complex tissues. Tissue Eng 2006, 12:3307-3339.

10. Dvir T, Timko BP, Kohane DS, Langer R: Nanotechnological strategies for engineering complex tissues. Nat.Nanotechnol. 2011, 6:13-22.

11. Atala A, Kasper FK, Mikos AG: Engineering complex tissues. Sci.Transl.Med 2012, 4:160rv12.

12. Woo SL, Maynard J, Butler DL, Lyon RM, Torzilli PA, Akeson WH, Cooper RR, Oakes B: Ligament, tendon, and joint capsule insertions to bone. In Injury and Repair of the Musculosketal Soft Tissues. Edited by Woo SL, Buckwalter JA. Savannah, GA: American Academy of Orthopaedic Surgeons; 1988:133-166.

13. Quain J: Elements of anatomy: In 3 volumes. New York, NY: Walton and Maberly; 1856.

14. Costa PF, Vaquette $C_{+}$, Zhang Q, Reis RL, Ivanovski S, Hutmacher DW: Advanced tissue engineering scaffold design for regeneration of the complex hierarchical periodontal structure. Journal of Clinical Periodontology 2014, 41:283-294.

15. Park $\mathrm{CH}$, Rios HF, Jin Q, Bland ME, Flanagan CL, Hollister SJ, Giannobile WV: Biomimetic hybrid scaffolds for engineering human tooth-ligament interfaces. Biomaterials 2010, 31:5945-5952.

16. Park $\mathrm{CH}$, Rios HF, Jin Q, Sugai JV, Padial-Molina M, Taut AD, Flanagan CL, Hollister SJ, Giannobile WV: Tissue engineering bone-ligament complexes using fiberguiding scaffolds. Biomaterials 2012, 33:137-145.

17. Park CH, Rios HF, Taut AD, Padial-Molina M, Flanagan CL, Pilipchuk SP, Hollister SJ, Giannobile WV: Image-based, fiber guiding scaffolds: a platform for regenerating tissue interfaces. Tissue Eng Part C.Methods 2014, 20:533-542.

${ }^{* *}$ Solid free-form fabrication was used to produce scaffolds with functionally-oriented microchannels to facilitate the regeneration of bone-ligament complexes. Using imagebased methods, the scaffold can be customized to fit anatomic defects. The fiber guiding channels resulted in enhanced organization of the ligament interface in surgically created defects in vivo.

18. Lee $\mathrm{CH}$, Hajibandeh J, Suzuki T, Fan A, Shang P, Mao JJ: Three-Dimensional Printed Multiphase Scaffolds for Regeneration of Periodontium Complex. Tissue Eng.Pt.A 2014, 20:1342-1351. 
19. Matyas JR, Anton MG, Shrive NG, Frank CB: Stress governs tissue phenotype at the femoral insertion of the rabbit MCL. J Biomech. 1995, 28:147-157.

20. Spalazzi JP, Gallina J, Fung-Kee-Fung SD, Konofagou EE, Lu HH: Elastographic imaging of strain distribution in the anterior cruciate ligament and at the ligamentbone insertions. J.Orthop.Res 2006, 24:2001-2010.

21. Cooper RR, Misol S: Tendon and ligament insertion. A light and electron microscopic study. J.Bone Joint Surg.Am. 1970, 52:1-20.

22. Benjamin M, Evans EJ, Copp L: The histology of tendon attachments to bone in man. J.Anat. 1986, 149:89-100.

23. Moffat KL, Sun WH, Pena PE, Chahine NO, Doty SB, Ateshian GA, Hung CT, Lu HH: Characterization of the structure-function relationship at the ligament-to-bone interface. Proc.Natl.Acad.Sci.USA 2008, 105:7947-7952.

24. Spalazzi JP, Doty SB, Moffat KL, Levine WN, Lu HH: Development of controlled matrix heterogeneity on a triphasic scaffold for orthopedic interface tissue engineering. Tissue Eng 2006, 12:3497-3508.

25. Spalazzi JP, Dagher E, Doty SB, Guo XE, Rodeo SA, Lu HH: In vivo evaluation of a multiphased scaffold designed for orthopaedic interface tissue engineering and soft tissue-to-bone integration. J.Biomed.Mater.Res.A. 2008, 86:1-12.

26. Subramony SD, Qu D, Ma R, Schaer M, Guo XE, Doty S.B., Rodeo SA, Lu H.H.: In vitro optimization and in vivo evaluation of a multi-phased nanofiber-based synthetic ACL scaffold [abstract]. Transactions of the 60th Orthopaedic Research Society 2014.

27. Wang Z, Zhang Y, Zhu J, Dong S, Jiang T, Zhou Y, Zhang X: In vitro investigation of a tissue-engineered cell-tendon complex mimicking the transitional architecture at the ligament-bone interface. Journal of Biomaterials Applications 2015, 29:1180-1192.

*Decellularized rabbit tendons were regionally seeded with genetically modified cells to support fibrogenesis, chrondrogenesis, or osteogenesis. In this manner, the authors were able to engineer a continuous and heterogeneous transition region, mimetic of the native ligament insertion. Tissue specific gene expression profiles and matrix formation was observed.

28. Phillips JE, Burns KL, Le Doux JM, Guldberg RE, Garcia AJ: Engineering graded tissue interfaces. Proc.Natl.Acad.Sci.USA 2008, 105:12170-12175.

29. Samavedi S, Olsen Horton C, Guelcher SA, Goldstein AS, Whittington AR: Fabrication of a model continuously graded co-electrospun mesh for regeneration of the ligament-bone interface. Acta.Biomater 2011, 7:4131-4138.

30. Samavedi S, Guelcher SA, Goldstein AS, Whittington AR: Response of bone marrow stromal cells to graded co-electrospun scaffolds and its implications for engineering the ligament-bone interface. Biomaterials 2012, 33:7727-7735. 
31. Samavedi S, Vaidya P, Gaddam P, Whittington AR, Goldstein AS: Electrospun meshes possessing region-wise differences in fiber orientation, diameter, chemistry and mechanical properties for engineering bone-ligament-bone tissues. Biotechnol.Bioeng. 2014.

32. Blevins FT, Djurasovic M, Flatow EL, Vogel KG: Biology of the rotator cuff tendon. Orthop.Clin.North Am. 1997, 28:1-16.

33. Moffat KL, Cassilly RT, Subramony SD, Dargis BR, Zhang X, Liu X, Guo XE, Doty SB, Levine WN, Lu HH: In vivo evaluation of a bi-phasic nanofiber-based scaffold for integrative rotator cuff repair [abstract]. Transactions of the 56th Orthopaedic Research Society 2010.

34. Zhang X, Caldwell JM, Easley J, Hackett E, Doty S, Levine W, Guo X, Lu H: In vivo evaluation of a biomimetic biphasic scaffold in sheep [abstract]. Transactions of the 60th Orthopaedic Research Society 2014.

35. Genin GM, Kent A, Birman V, Wopenka B, Pasteris JD, Marquez PJ, Thomopoulos S: Functional grading of mineral and collagen in the attachment of tendon to bone. Biophysical Journal 2009, 97:976-985.

36. Li XR, Xie JW, Lipner J, Yuan XY, Thomopoulos S, Xia YN: Nanofiber scaffolds with gradations in mineral content for mimicking the tendon-to-bone insertion site. Nano Lett. 2009, 9:2763-2768.

37. Dickerson DA, Misk TN, Van S, Breur GJ, Nauman EA: In vitro and in vivo evaluation of orthopedic interface repair using a tissue scaffold with a continuous hard tissue-soft tissue transition. J.Orthop.Surg.Res. 2013, 8:18.

${ }^{*}$ Cancellous bone scaffolds were regionally demineralized, resulting in an outer ring of partially demineralized structure, and an inner mineralized core, resulting in a continuous hard-tosoft tissue transition. Upon implantation in an ovine rotator cuff tendon model, the formation of a fibrocartilaginous interface was observed.

38. Liu W, Lipner J, Xie J, Manning CN, Thomopoulos S, Xia Y: Nanofiber scaffolds with gradients in mineral content for spatial control of osteogenesis. ACS Appl.Mater.Interfaces. 2014, 6:2842-2849.

${ }^{* *} A$ spatial gradient in mineral content, spanning $5 \mathrm{~cm}$, was formed on nanofiber scaffolds through region specific soaking in a simulated body fluid solution. The scaffold was able to direct the graded differentiation of adipose derived stem cells into osteoblasts necessary for tendon-to-bone healing.

39. Zhen G, Cao X: Targeting TGFbeta signaling in subchondral bone and articular cartilage homeostasis. Trends Pharmacol.Sci. 2014, 35:227-236.

40. Mente PL, Lewis JL: Elastic modulus of calcified cartilage is an order of magnitude less than that of subchondral bone. J.Orthop.Res. 1994, 12:637-647. 
41. Soltz MA, Ateshian GA: Experimental verification and theoretical prediction of cartilage interstitial fluid pressurization at an impermeable contact interface in confined compression. J.Biomech. 1998, 31:927-934.

42. Redler I, Mow VC, Zimny ML, Mansell J: The ultrastructure and biomechanical significance of the tidemark of articular cartilage. Clin.Orthop.Relat Res. 1975,357362.

43. Bullough PG, Jagannath A: The morphology of the calcification front in articular cartilage. Its significance in joint function. J.Bone Joint Surg.Br. 1983, 65:72-78.

44. Hunziker EB, Driesang IM, Saager C: Structural barrier principle for growth factorbased articular cartilage repair. Clin.Orthop.Relat Res. 2001,S182-S189.

45. Holmes B, Zhu W, Li J, Lee JD, Zhang LG: Development of novel three-dimensional printed scaffolds for osteochondral regeneration. Tissue Eng.Pt.A 2014, 21 :403415.

**The authors fabricated biphasic 3D printed PLA scaffolds that mimic the native architecture of cartilage and bone and include an interlocking "key structure". The biphasic scaffolds exhibited enhanced shear modulus at the interphase compared to homogenous (nonbiphasic) scaffolds and increased gene expression and matrix production of regionspecific cartilage and bone markers. This work highlights the potential to utilize technologies that promote the fabrication of physiologically-relevant regions within scaffolds to stimulate multi-tissue regeneration.

46. Lu HH, Jiang J, Tang A, Hung CT, Guo XE: Development of controlled heterogeneity on a polymer-ceramic hydrogel scaffold for osteochondral repair. Bioceramics 2005, 17:607-610.

47. Jiang J, Tang A, Ateshian GA, Guo XE, Hung CT, Lu HH: Bioactive stratified polymer ceramic-hydrogel scaffold for integrative osteochondral repair. Ann.Biomed.Eng. 2010, 38:2183-2196.

48. Kandel RA, Hurtig M, Grynpas M: Characterization of the mineral in calcified articular cartilagenous tissue formed in vitro. Tissue Eng 1999, 5:25-34.

49. Allan KS, Pilliar RM, Wang J, Grynpas MD, Kandel RA: Formation of biphasic constructs containing cartilage with a calcified zone interface. Tissue Eng 2007, 13:167-177.

50. Khanarian NT, Jiang J, Wan LQ, Mow VC, Lu HH: A hydrogel-mineral composite scaffold for osteochondral interface tissue engineering. Tissue Eng.Pt.A 2012, 18:533-545.

51. Khanarian NT, Haney NM, Burga RA, Lu HH: A functional agarose-hydroxyapatite scaffold for osteochondral interface regeneration. Biomaterials 2012, 33:5427-5258.

52. Mellor LF, Mohiti-Asli M, Williams J, Kannan A, Dent MR, Guilak F, Loboa EG:

Extracellular Calcium Modulates Chondrogenic and Osteogenic Differentiation of 
Human Adipose-Derived Stem Cells: A Novel Approach for Osteochondral Tissue Engineering Using a Single Stem Cell Source. Tissue Eng.Pt.A 2015, $21: 2323-2333$.

53. Aviv-Gavriel M, Garti N, Furedi-Milhofer H: Preparation of a partially calcified gelatin membrane as a model for a soft-to-hard tissue interface. Langmuir 2013, 29:683689.

54. Harley BA, Lynn AK, Wissner-Gross Z, Bonfield W, Yannas IV, Gibson LJ: Design of a multiphase osteochondral scaffold III: Fabrication of layered scaffolds with continuous interfaces. J.Biomed.Mater.Res.A. 2010, 92:1078-1093.

55. Getgood AM, Kew SJ, Brooks R, Aberman H, Simon T, Lynn AK, Rushton N: Evaluation of early-stage osteochondral defect repair using a biphasic scaffold based on a collagen-glycosaminoglycan biopolymer in a caprine model. Knee. 2012, 19:422-430.

56. Khanarian NT, Boushell MK, Spalazzi JP, Pleshko N, Boskey AL, Lu HH: FTIR-I compositional mapping of the cartilage-to-bone interface as a function of tissue region and age. J.Bone Miner.Res. 2014.

57. Huang GX, Arany PR, Mooney DJ: Modeling and Validation of Multilayer PLG Scaffolds for in vitro Directed Differentiation of Juxtaposed Cartilage and Bone. Tissue Eng 2015.

${ }^{* *}$ The authors developed a mathematic model for the spatiotemporal release of TGF- $\beta 3$ (cartilage) and BMP-4 (bone) and their respective antibodies in poly(lactide-co-glycolide) (PLG) microsphere-based scaffolds in vitro. The localized delivery of growth factors and inhibitors promoted region-specific gene expression of cartilage and bone markers. This work illustrates the potential to develop mathematical models that predict the release of bioactive cues (e.g. mineral, growth factors) for smart materials that mimic the native release profiles.

58. Chen G, Sato T, Tanaka J, Tateishi T: Preparation of a biphasic scaffold for osteochondral tissue engineering. Mater.Sci.Eng.C 2006, 26:118-123.

59. Chen J, Chen H, Li P, Diao H, Zhu S, Dong L, Wang R, Guo T, Zhao J, Zhang J: Simultaneous regeneration of articular cartilage and subchondral bone in vivo using MSCs induced by a spatially controlled gene delivery system in bilayered integrated scaffolds. Biomaterials 2011, 32:4793-4805.

60. Erisken C, Kalyon DM, Wang HJ, Ornek-Ballanco C, $\mathrm{Xu} \mathrm{JH}$ : Osteochondral Tissue Formation Through Adipose-Derived Stromal Cell Differentiation on Biomimetic Polycaprolactone Nanofibrous Scaffolds with Graded Insulin and BetaGlycerophosphate Concentrations. Tissue Eng.Pt.A 2011, 17:1239-1252.

61. Re'em T, Witte F, Willbold E, Ruvinov E, Cohen S: Simultaneous regeneration of articular cartilage and subchondral bone induced by spatially presented TGF-beta and BMP-4 in a bilayer affinity binding system. Acta.Biomater 2012, 8:3283-3293. 
62. Zou B, Liu Y, Luo X, Chen F, Guo X, Li X: Electrospun fibrous scaffolds with continuous gradations in mineral contents and biological cues for manipulating cellular behaviors. Acta.Biomater 2012, 8:1576-1585.

63. Spalazzi JP, Boskey AL, Pleshko N, Lu HH: Quantitative mapping of matrix content and distribution across the ligament-to-bone insertion. PLOS ONE 2013, 8.

64. Mann KA, Ayers DC, Werner FW, Nicoletta RJ, Fortino MD: Tensile strength of the cement-bone interface depends on the amount of bone interdigitated with PMMA cement. J Biomech. 1997, 30:339-346.

65. Li Y, Ortiz C, Boyce MC: Stiffness and strength of suture joints in nature. Phys.Rev.E.Stat.Nonlin.Soft.Matter Phys. 2011, 84:062904.

66. Wang IE, Shan J, Choi R, Oh S, Kepler CK, Chen FH, Lu HH: Role of osteoblastfibroblast interactions in the formation of the ligament-to-bone interface. J.Orthop.Res. 2007, 25:1609-1620.

67. Wang IE, Mitroo S, Chen FH, Lu HH, Doty SB: Age-dependent changes in matrix composition and organization at the ligament-to-bone insertion. J.Orthop.Res. 2006, 24:1745-1755.

68. Milz S, Rufai A, Buettner A, Putz R, Ralphs JR, Benjamin M: Three-dimensional reconstructions of the Achilles tendon insertion in man. J.Anat. 2002, 200:145-152.

69. Benjamin M, Kumai T, Milz S, Boszczyk BM, Boszczyk AA, Ralphs JR: The skeletal attachment of tendons--tendon "entheses". Comp Biochem.Physiol A Mol.Integr.Physiol 2002, 133:931-945.

70. Wang IE, Mitroo S, Chen FH, Lu HH, Doty SB: Age-dependent changes in matrix composition and organization at the ligament-to-bone insertion. J.Orthop.Res. 2006, 24:1745-1755.

71. Lu HH, Thomopoulos S: Functional attachment of soft tissues to bone: development, healing, and tissue engineering. Annu.Rev.Biomed.Eng 2013, 15:201226.

72. Larkin LM, Calve S, Kostrominova TY, Arruda EM: Structure and functional evaluation of tendon-skeletal muscle constructs engineered in vitro. Tissue Eng 2006, 12:3149-3158.

73. Bosshardt DD, Bergomi M, Vaglio G, Wiskott A: Regional structural characteristics of bovine periodontal ligament samples and their suitability for biomechanical tests. J.Anat. 2008, 212:319-329.

74. Nanci A, Bosshardt DD: Structure of periodontal tissues in health and disease. Periodontol.2000. 2006, 40:11-28.

75. Ho SP, Kurylo MP, Fong TK, Lee SS, Wagner HD, Ryder MI, Marshall GW: The biomechanical characteristics of the bone-periodontal ligament-cementum complex. Biomaterials 2010, 31:6635-6646. 
76. Raspanti M, Cesari C, De Pasquale V, Ottani V, Strocchi R, Zucchelli G, Ruggeri A: A histological and electron-microscopic study of the architecture and ultrastructure of human periodontal tissues. Arch.Oral.Biol 2000, 45:185-192.

77. Schwartz AG, Pasteris JD, Genin GM, Daulton TL, Thomopoulos S: Mineral distributions at the developing tendon-to-bone insertion. PlosOne 2012,-In Press.

78. Thomopoulos S, Williams GR, Gimbel J.A., Favata M, Soslowsky LJ: Variations of biomechanical, structural, and compositional properties along the tendon to bone insertion site. J Orthop Res 2003, 21:413-419.

79. Wopenka B, Kent A, Pasteris JD, Yoon Y, Thomopoulos S: The tendon-to-bone transition of the rotator cuff: a preliminary Raman spectroscopic study documenting the gradual mineralization across the insertion in rat tissue samples. Appl.Spectrosc. 2008, 62:1285-1294.

80. Lane LB, Bullough PG: Age-related changes in the thickness of the calcified zone and the number of tidemarks in adult human articular cartilage. J.Bone Joint Surg.Br. 1980, 62:372-375.

81. Muller-Gerbl M, Schulte E, Putz R: The thickness of the calcified layer in different joints of a single individual. Acta Morphol.Neerl.Scand. 1987, 25:41-49.

82. Hunziker EB, Quinn TM, Hauselmann HJ: Quantitative structural organization of normal adult human articular cartilage. Osteoarthr.Cartilage 2002, 10:564-572.

83. Bottino $\mathrm{MC}$, Thomas $\mathrm{V}$, Janowski GM: A novel spatially designed and functionally graded electrospun membrane for periodontal regeneration. Acta.Biomater 2011, 7:216-224.

84. Vaquette $\mathrm{C}+$, Fan W, Xiao Y, Hamlet S, Hutmacher DW, Ivanovski S: A biphasic scaffold design combined with cell sheet technology for simultaneous regeneration of alveolar bone/periodontal ligament complex. Biomaterials 2012, 33:5560-5573.

85. He J, Zhang W, Liu Y, Li X, Li D, Jin Z: Design and fabrication of biomimetic multiphased scaffolds for ligament-to-bone fixation. Mater.Sci.Eng.C 2015, 50:1218.

86. Moffat $\mathrm{KL}$, Levine $\mathrm{WN}$, Lu HH: In vitro evaluation of rotator cuff tendon fibroblasts on aligned composite scaffold of polymer nanofibers and hydroxyapatite nanoparticles [abstract]. Transactions of the 54th Orthopaedic Research Society 2008.

87. Amadori S, Torricelli P, Panzavolta S, Parrilli A, Fini M, Bigi A: Highly Porous Gelatin Reinforced 3D Scaffolds for Articular Cartilage Regeneration. Macromolecular Bioscience 2015, 15:941-952.

88. Kon E, Filardo G, Robinson D, Eisman JA, Levy A, Zaslav K, Shani J, Altschuler N: Osteochondral regeneration using a novel aragonite-hyaluronate bi-phasic scaffold in a goat model. Knee Surg.Sports Traumatol.Arthrosc. 2014, 22:1452-1464. 
*The authors utilized a goat osteochondral defect model to investigate the effect of hydroxyapatite (HA) in the cartilage phase and drilled channels in the cartilage or bone phase of coralline aragonite scaffolds on the integrative osteochondral repair. The scaffolds with channels and HA impregnated in the cartilage phase showed integrated healing based on immunohistochemical scaling compared to all other scaffold designs tested. These promising results in a large animal model yield promise for translation into human osteochondral repair.

89. Liu S, Wu J, Liu X, Chen D, Bowlin GL, Cao L, Lu J, Li F, Mo X, Fan C: Osteochondral regeneration using an oriented nanofiber yarn-collagen type $\mathrm{I} / \mathrm{hy}$ aluronate hybrid/TCP biphasic scaffold. J.Biomed.Mater.Res.A. 2015, 103:581-592.

90. Koushki N, Katbab AA, Tavassoli H, Jahanbakhsh A, Majidi M, Bonakdar S: A new injectable biphasic hydrogel based on partially hydrolyzed polyacrylamide and nanohydroxyapatite as scaffold for osteochondral regeneration. RSC Advances 2015, 5:9089-9096. 


\section{List of Tables and Figures}

Table 1. Dimensions of native tissue-tissue transitions. *Note: Values were estimated using Image J by authors based on ${ }^{1}$ Figure 6 of Wang et al. [67], ${ }^{2}$ Figure 2 of Milz et al. [68], and ${ }^{3}$ Figure 1 of Benjamin et al. [69].

Table 2. Composite scaffold designs for integrative ligament tissue engineering. *Note: Tissue formation was determined by staining, immunohistochemistry, or gene expression for pertinent matrix components (ligament: collagen, collagen I, and/or collagen III; fibrocartilage: glycosaminoglycans (GAG) and collagen; mineralized fibrocartilage: GAG, collagen, and mineral; bone: mineral and/or ALP). $\beta$-TCP: $\beta$-tricalcium phosphate; BMP: bone morphogenetic protein; BMSCs: bone marrow-derived mesenchymal stem cells; $\underline{\mathrm{CaP}}$ : calcium phosphate; $\underline{\mathrm{CDA}}$

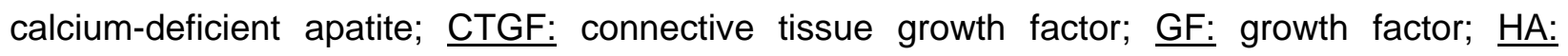

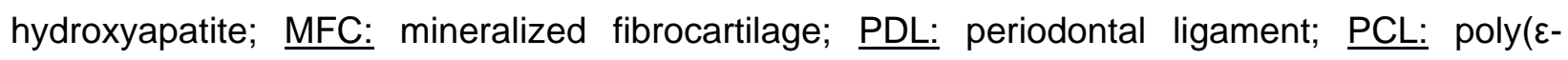
caprolactone); PGA: poly(glycolic acid); PLA: poly(lactic acid); PLGA: poly(glycolic-co-lactic acid); PUR: poly(ester urethane urea); $\underline{\mathrm{RUNX}-2:}$ runt-related transcription factor; $\underline{\text { SOX-9: }}$ sex determining region Y-box 9

Table 3. Composite scaffold designs for integrative tendon tissue engineering (tendon-bone). *Note: Tissue formation was determined by staining, immunohistochemistry, or gene expression for pertinent matrix components (tendon: collagen, collagen I, and/or collagen III; fibrocartilage: glycosaminoglycans (GAG) and collagen; mineralized fibrocartilage: GAG, collagen, and mineral; bone: mineral and/or ALP). ADSCs: adipose-derived mesenchymal stem cells; $\underline{\text { HA: }}$ hydroxyapatite; MFC: mineralized fibrocartilage; PLA: poly(lactic acid); PLGA: poly(glycolic-colactic acid); $\underline{R U N X-2:}$ runt-related transcription factor

Table 4. Composite scaffold designs for integrative cartilage tissue engineering. ${ }^{*}$ Note: Tissue formation was determined by staining, immunohistochemistry, or gene expression for pertinent 
matrix components (cartilage: GAG and collagen II; calcified cartilage: collagen $\mathrm{X}$ or glycosaminoglycan (GAG) and mineral; bone: mineral, calcium deposition, collagen I, bone sialoprotein and/or ALP). $\underline{\text { ADSCs: }}$ adipose-derived mesenchymal stem cells; BG: bioactive glass; $\underline{\beta-G P}$ : $\beta$-glycerophosphate; $\underline{\beta-T C P}$ : $\beta$-tricalcium phosphate; $\mathrm{BMP}$ : bone morphogenetic protein; BMSCs: bone marrow-derived mesenchymal stem cells; $\underline{\mathrm{CaP}}$ : calcium phosphate; $\underline{\mathrm{CC}}$ :

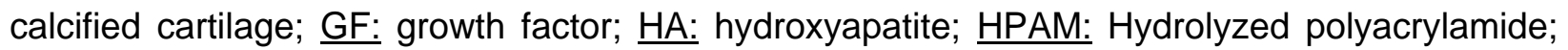
PCL: $\operatorname{poly}(\varepsilon$-caprolactone); PLA: poly(lactic acid); PLGA: poly(glycolic-co-lactic acid); $\underline{\text { TGF: }}$ transforming growth factor

Figure 1. Common tissue-tissue interfaces. Ligaments, such as the anterior cruciate ligament $(A C L)$ in the knee (Modified Goldner's Masson Trichrome),[70] and tendons, such as the supraspinatus tendon in the shoulder (Toluidine blue),[71] connect to bone via a fibrocartilaginous (FC) transition, which can be further subdivided into non-mineralized (NFC) and mineralized (MFC) regions (Von Kossa). The periodontal ligament of the tooth (Modified Goldner's Masson Trichrome) connects indirectly to bone through Shapery's fibers insertions. The muscle-tendon junction (Modified Goldner's Masson Trichrome) consists of an interdigitating band of connective tissue.[72] Cartilage connects to subchondral bone via a transitional calcified cartilage (CC) region (Von Kossa). 


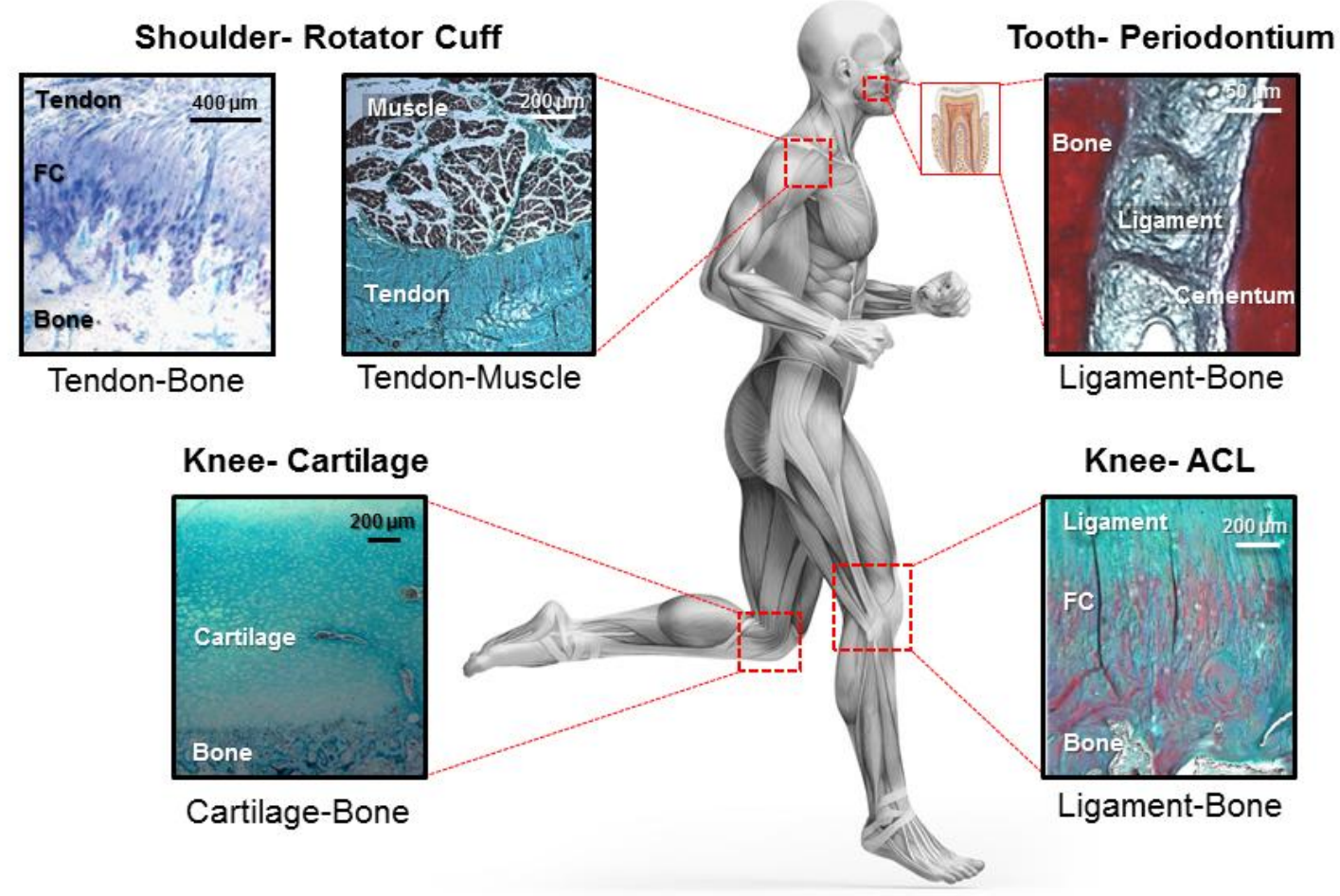




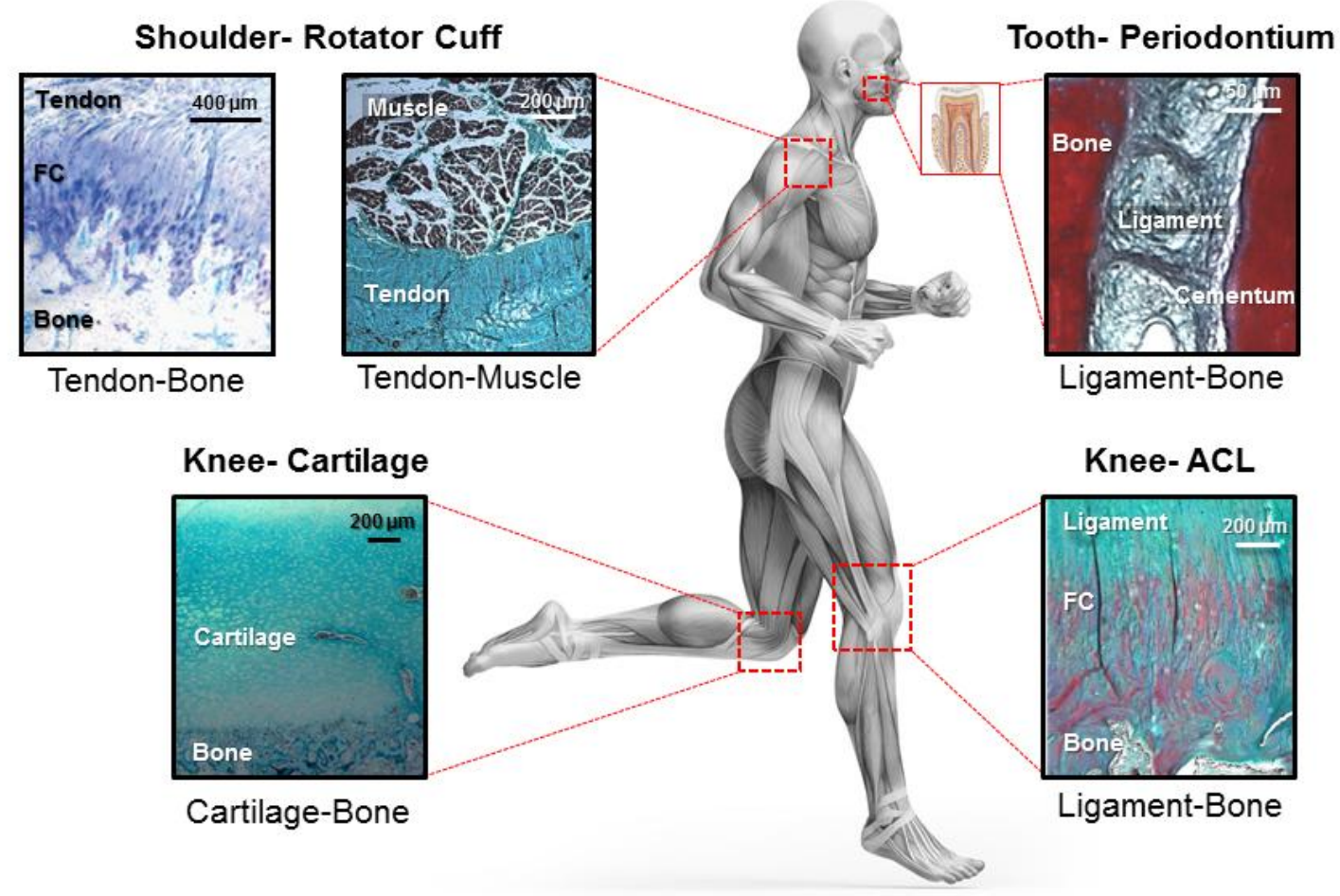


Table 1. Dimensions of Native Tissue-Tissue Transitions

\begin{tabular}{|c|c|c|c|c|}
\hline \multicolumn{5}{|c|}{ Ligament-Bone } \\
\hline $\begin{array}{l}\text { Composite } \\
\text { Tissues }\end{array}$ & Species & Age/Sex & $\begin{array}{l}\text { Tissue Transition } \\
\text { Thickness }\end{array}$ & Calcified Region \\
\hline $\begin{array}{l}\text { ACL-Bone (femoral } \\
\text { and tibial } \\
\text { insertions) }\end{array}$ & Bovine & $\begin{array}{c}\text { Neonatal ( } 1-7 \text { days) }(\mathrm{M}) \\
\text { Immature (4-6 months) }(\mathrm{M}) \\
\text { Mature }(2-5 \text { years) }(\mathrm{M})\end{array}$ & $\begin{array}{l}780 \pm 3 \mu \mathrm{m}[67] \\
480 \pm 5 \mu \mathrm{m}[67] \\
356 \pm 4 \mu \mathrm{m}[67]\end{array}$ & $\begin{array}{c}300-400[67]^{1} \mu \mathrm{m} \\
150-165[67]^{1} \mu \mathrm{m} \\
40-120[67]^{1} \mu \mathrm{m}\end{array}$ \\
\hline $\begin{array}{l}\text { ACL-Bone (femoral } \\
\text { and tibial } \\
\text { insertions) }\end{array}$ & Bovine & Neonatal (1-7 days) (M) & $700-800 \mu \mathrm{m}[63]$ & $200-250 \mu \mathrm{m}[63]$ \\
\hline $\begin{array}{l}\text { Periodontal } \\
\text { Ligament-Bone }\end{array}$ & Bovine & - & 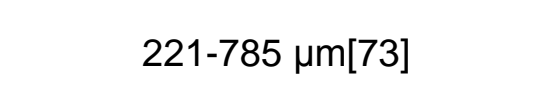 & - \\
\hline $\begin{array}{c}\text { Periodontal } \\
\text { Ligament-Bone }\end{array}$ & Human & $18-30$ years $(\mathrm{M} / \mathrm{F})$ & $200-500 \mu \mathrm{m}[74]$ & $\begin{array}{l}\text { 5-20 } \mu \mathrm{m}[75 ; 76] \text { (Cementum) } \\
\text { 5-10 } \mu \mathrm{m}[76] \text { (Alveolar bone) }\end{array}$ \\
\hline \multicolumn{5}{|c|}{ Tendon-Bone } \\
\hline $\begin{array}{l}\text { Supraspinatus } \\
\text { Tendon-Bone }\end{array}$ & Mouse & Postnatal (7 - 56 days) & -- & $20-25 \mu \mathrm{m}[77]$ \\
\hline $\begin{array}{l}\text { Supraspinatus } \\
\text { Tendon-Bone }\end{array}$ & Rat & Skeletally mature & $600-800 \mu \mathrm{m}[78]$ & $100-120 \mu \mathrm{m}[79]$ \\
\hline $\begin{array}{l}\text { Patellar Tendon- } \\
\text { Bone (patellar } \\
\text { insertion) }\end{array}$ & Canine & Adult & $250-450 \mu \mathrm{m}[21]$ & $100-300 \mu \mathrm{m}[21]$ \\
\hline $\begin{array}{c}\text { Achilles Tendon- } \\
\text { Bone }\end{array}$ & Human & Adult & $500-700 \mu m^{2}[68]$ & $230-400 \mu \mathrm{m}^{3}[69]$ \\
\hline \multicolumn{5}{|c|}{ Cartilage-Bone } \\
\hline $\begin{array}{l}\text { Cartilage-Bone } \\
\text { (tibial condyle) }\end{array}$ & Bovine & $\begin{array}{l}\text { Immature }(\mathrm{M}) \\
\text { Mature }(\mathrm{M})\end{array}$ & $\begin{array}{c}165 \pm 8 \mu \mathrm{m}[56] \\
174 \pm 46 \mu \mathrm{m}[56]\end{array}$ & $\begin{array}{c}165 \pm 8 \mu \mathrm{m}[56] \\
174 \pm 46 \mu \mathrm{m}[56]\end{array}$ \\
\hline $\begin{array}{c}\text { Cartilage-Bone } \\
\text { (humeral condyle) }\end{array}$ & Human & $25-93$ years & $\begin{array}{c}206-96 \mu \mathrm{m}[80] \\
\text { (thickness decreases with age) }\end{array}$ & $96-206 \mu \mathrm{m}[80]$ \\
\hline
\end{tabular}




\begin{tabular}{|c|c|c|c|c|}
\hline $\begin{array}{l}\text { Cartilage-Bone } \\
\text { (femoral condyle) }\end{array}$ & Human & $\begin{array}{c}25-93 \text { years }[80] \\
27-86 \text { years[81] }(\mathrm{M} / \mathrm{F}) \\
23-49 \text { years }[82](\mathrm{M} / \mathrm{F})\end{array}$ & $\begin{array}{c}243-79 \mu \mathrm{m}[80] \\
20-230 \mu \mathrm{m}[81] \\
134 \mu \mathrm{m}[82]\end{array}$ & $\begin{array}{c}79-243 \mu \mathrm{m}[80] \\
20-230 \mu \mathrm{m}[81] \\
134 \mu \mathrm{m}[82]\end{array}$ \\
\hline
\end{tabular}

*Note: Values were estimated using ImageJ by authors based on ${ }^{1}$ Figure 6 of Wang et al. [67], ${ }^{2}$ Figure 2 of Milz et al. [68], and ${ }^{3}$ Figure 1 of Benjamin et al. [69]. 
Table 2. Complex scaffold designs for integrative ligament tissue engineering

\begin{tabular}{|c|c|c|c|c|c|}
\hline \multicolumn{6}{|c|}{ Stratified Scaffold Designs } \\
\hline Study & Material and Scaffold Design & Induction Agents & Cell Source & Animal Model & Tissues Formed ${ }^{\star}$ \\
\hline $\begin{array}{l}\text { Subramony } \\
\text { et al. } \\
2014[26]\end{array}$ & $\begin{array}{l}\text { Braided PCL-PLGA fibers } \\
\text { (ligament) with braided PCL- } \\
\text { PLGA-HA fiber ends (bone), } \\
\text { wrapped with biphasic } \\
\text { PLGA/PLGA-HA fiber collars } \\
\text { (interface) }\end{array}$ & HA (MFC, bone) & Rat BMSCs & $\begin{array}{l}\text { Rat } A C L \\
\text { reconstruction }\end{array}$ & $\begin{array}{l}\text { Ligament } \\
\text { Fibrocartilage } \\
\text { Bone }\end{array}$ \\
\hline $\begin{array}{l}\text { Wang et al. } \\
2015[27]\end{array}$ & $\begin{array}{l}\text { Decellularized rabbit achilles } \\
\text { tendon with region specific cell } \\
\text { seeding }\end{array}$ & $\begin{array}{l}\text { RUNX-2 (bone) } \\
\text { and SOX-9 } \\
\text { (cartilage) } \\
\text { adenovirus }\end{array}$ & $\begin{array}{l}\text { Rabbit fibroblasts, } \\
\text { chondrocytes, and } \\
\text { osteoblasts }\end{array}$ & - & $\begin{array}{l}\text { Ligament } \\
\text { Fibrocartilage } \\
\text { Bone }\end{array}$ \\
\hline $\begin{array}{l}\text { Bottino et al. } \\
2011[83]\end{array}$ & $\begin{array}{l}\text { PLA-PCL fibers (PDL), PLA- } \\
\text { Gelatin-HA fibers (bone), and } \\
\text { PLA-Gelatin-metronidazole } \\
\text { (epithelial) }\end{array}$ & HA (bone) & - & - & - \\
\hline $\begin{array}{l}\text { Park et al. } \\
2010[15]\end{array}$ & $\begin{array}{l}\text { 3D printed PGA channels } \\
\text { (ligament) fused to solvent cast } \\
\text { PCL (bone) }\end{array}$ & BMP-7 adenovirus & $\begin{array}{l}\text { Human PDL } \\
\text { fibroblasts }\end{array}$ & $\begin{array}{l}\text { Murine } \\
\text { subcutaneous } \\
\text { implant }\end{array}$ & $\begin{array}{l}\text { Cementum } \\
\text { PDL } \\
\text { Bone }\end{array}$ \\
\hline $\begin{array}{l}\text { Park et al. } \\
\text { 2012[16] }\end{array}$ & $\begin{array}{l}\text { PCL custom fit to anatomical } \\
\text { defect with fiber guiding } \\
\text { channels specific to PDL- } \\
\text { interface and bone }\end{array}$ & BMP-7 adenovirus & $\begin{array}{l}\text { Human PDL } \\
\text { fibroblasts }\end{array}$ & $\begin{array}{l}\text { Rat fenestration } \\
\text { defect }\end{array}$ & $\begin{array}{l}\text { Cementum } \\
\text { PDL } \\
\text { Bone }\end{array}$ \\
\hline $\begin{array}{l}\text { Lee et al. } \\
2014[18]\end{array}$ & $\begin{array}{l}\text { 3D printed PCL-HA with varied } \\
\text { channel geometry } 100 \mu \mathrm{m} \\
\text { (cementum), } 600 \mu \mathrm{m}(P D L) \\
300 \mu \mathrm{m} \text { (bone) with region } \\
\text { specific GF seeding }\end{array}$ & $\begin{array}{l}\text { PLGA } \\
\text { microspheres with } \\
\text { amelogenin } \\
\text { (cementum), } \\
\text { CTGF (PDL), } \\
\text { BMP-2 (bone) } \\
\end{array}$ & $\begin{array}{l}\text { Human dental } \\
\text { pulp stem cells, } \\
\text { PDL stem cells, or } \\
\text { alveolar bone } \\
\text { stem cells }\end{array}$ & $\begin{array}{l}\text { Murine } \\
\text { subcutaneous } \\
\text { implant }\end{array}$ & $\begin{array}{l}\text { Cementum } \\
\text { PDL with Sharpey's } \\
\text { fibers }\end{array}$ \\
\hline $\begin{array}{l}\text { Vaquette et } \\
\text { al. 2012[84] }\end{array}$ & $\begin{array}{l}\text { Fused deposition modelling } \\
\text { PCL- } \beta \text {-TCP (bone), PCL fibers } \\
(P D L)\end{array}$ & $\beta$-TCP (bone) & $\begin{array}{l}\text { Ovine osteoblasts } \\
\text { and PDL } \\
\text { fibroblasts }\end{array}$ & $\begin{array}{l}\text { Rat subcutaneous } \\
\text { implant }\end{array}$ & $\begin{array}{l}\text { Cementum } \\
\text { PDL } \\
\text { Bone }\end{array}$ \\
\hline
\end{tabular}




\begin{tabular}{|c|c|c|c|c|c|}
\hline $\begin{array}{l}\text { Costa et al. } \\
2014[14]\end{array}$ & $\begin{array}{l}\text { Fused deposition modelling } \\
\text { PCL- } \beta \text {-TCP with CaP coating } \\
\text { (bone), PCL fibers (PDL) }\end{array}$ & $\begin{array}{l}\beta \text {-TCP, CaP } \\
\text { coating }\end{array}$ & $\begin{array}{l}\text { Ovine osteoblasts } \\
\text { and PDL } \\
\text { fibroblasts }\end{array}$ & $\begin{array}{l}\text { Rat subcutaneous } \\
\text { implant }\end{array}$ & $\begin{array}{l}\text { PDL } \\
\text { Bone }\end{array}$ \\
\hline \multicolumn{6}{|c|}{ Gradient Scaffold Designs } \\
\hline Study & Material and Scaffold Design & Induction Agents & Cell Source & Animal Model & Tissues Formed* \\
\hline $\begin{array}{l}\text { Samavedi et } \\
\text { al. 2011[29], } \\
2012[30]\end{array}$ & $\begin{array}{l}\text { PUR fibers (ligament) with } \\
\text { gradient to PCL-HA fibers (bone) }\end{array}$ & $\begin{array}{l}\mathrm{HA}, \mathrm{CDA}(\mathrm{MFC}, \\
\text { bone) }\end{array}$ & $\begin{array}{l}\text { Murine MC3T3 } \\
\text { osteoprogenitor } \\
\text { cells,[29] } \\
\text { Rat BMSCs[30] }\end{array}$ & - & - \\
\hline $\begin{array}{l}\text { Samavedi et } \\
\text { al. 2014[31] }\end{array}$ & $\begin{array}{l}\text { Aligned PCL fibers (ligament) } \\
\text { with gradient to unaligned PLGA } \\
\text { fibers (bone) }\end{array}$ & & Rat BMSCs & - & - \\
\hline $\begin{array}{l}\text { He et al. } \\
2015[85]\end{array}$ & $\begin{array}{l}\text { PLA microfibers (ligament), } \\
\text { PLGA with gradient ( } 8.6 \% \text {, } \\
2.7 \%, 0 \%) \beta-T C P(M F C, N F C) \text {, } \\
\text { and } \beta-T C P \text { and PCL anchor } \\
\text { (bone) }\end{array}$ & $\begin{array}{l}\beta-\mathrm{TCP}(\mathrm{MFC}, \\
N F C, \text { bone) }\end{array}$ & - & Porcine joint & - \\
\hline
\end{tabular}


Table 3. Complex scaffold designs for integrative tendon tissue engineering (tendon-bone)

\begin{tabular}{|c|c|c|c|c|c|}
\hline \multicolumn{6}{|c|}{ Stratified Scaffold Designs } \\
\hline Study & Material and Scaffold Design & Induction Agents & Cell Source & Animal Model & Tissues Formed* \\
\hline $\begin{array}{l}\text { Dickerson et } \\
\text { al. 2013[37] }\end{array}$ & $\begin{array}{l}\text { Demineralized bone construct } \\
\text { (tendon) with non-demineralized } \\
\text { bone end }\end{array}$ & - & - & $\begin{array}{l}\text { Ovine rotator cuff } \\
\text { repair }\end{array}$ & $\begin{array}{l}\text { Fibrocartilage } \\
\text { Mineralized } \\
\text { fibrocartilage } \\
\text { Bone }\end{array}$ \\
\hline $\begin{array}{l}\text { Moffat et al. } \\
2008[86] \text {, } \\
2010[33] ; \\
\text { Zhang et al. } \\
2014[34]\end{array}$ & $\begin{array}{l}\text { Patch with parallel PLGA and } \\
\text { PLGA-HA fiber regions } \\
\text { (interface) }\end{array}$ & $\mathrm{HA}(M F C)$ & $\begin{array}{l}\text { Bovine tendon } \\
\text { fibroblasts, } \\
\text { Bovine full } \\
\text { thickness } \\
\text { chondrocytes }\end{array}$ & $\begin{array}{l}\text { Rat subcutaneous } \\
\text { implant,[33] } \\
\text { Rat rotator cuff } \\
\text { repair,[28;33] } \\
\text { Ovine rotator cuff } \\
\text { repair[28] }\end{array}$ & $\begin{array}{l}\text { Fibrocartilage } \\
\text { Mineralized } \\
\text { fibrocartilage }\end{array}$ \\
\hline \multicolumn{6}{|c|}{ Gradient Scaffold Designs } \\
\hline Study & Material and Scaffold Design & Induction Agents & Cell Source & Animal Model & Tissues Formed $^{\star}$ \\
\hline $\begin{array}{l}\text { Phillips et al. } \\
2008 \text { [28] }\end{array}$ & $\begin{array}{l}\text { Fibrous collagen constructs (soft } \\
\text { tissue) with graded RUNX-2 } \\
\text { retrovirus coating (bone) }\end{array}$ & $\begin{array}{l}\text { RUNX-2 retrovirus } \\
\text { (MFC, bone) }\end{array}$ & $\begin{array}{l}\text { Rat skin } \\
\text { fibroblasts }\end{array}$ & $\begin{array}{l}\text { Rat subcutaneous } \\
\text { implant }\end{array}$ & Bone \\
\hline $\begin{array}{l}\text { Zou et al. } \\
2012[62]\end{array}$ & $\begin{array}{l}\text { PLA fibers (tendon) with graded } \\
\text { HA coating (bone) }\end{array}$ & $\mathrm{HA}$ (MFC, bone) & $\begin{array}{l}\text { Murine MC3T3 } \\
\text { osteoprogenitor } \\
\text { cells }\end{array}$ & - & - \\
\hline $\begin{array}{l}\text { Li et al. } \\
2009[36] \\
\text { Liu et al., } \\
2014[38]\end{array}$ & $\begin{array}{l}\text { PLGA fibers (tendon) with } \\
\text { graded HA coating (bone) }\end{array}$ & $\mathrm{HA}$ (MFC, bone) & $\begin{array}{l}\text { Murine MC3T3 } \\
\text { osteoprogenitor } \\
\text { cells,[36] } \\
\text { Rat ADSCs[38] }\end{array}$ & - & Bone \\
\hline
\end{tabular}


Table 4. Complex scaffold designs for integrative cartilage tissue engineering

\begin{tabular}{|c|c|c|c|c|c|}
\hline \multicolumn{6}{|c|}{ Stratified Scaffold Designs } \\
\hline Study & Material and Scaffold Design & Induction Agents & Cell Source & Animal Model & Tissues Formed* \\
\hline $\begin{array}{l}\text { Chen et al. } \\
2011[59]\end{array}$ & $\begin{array}{l}\text { Plasmid GF-activated chitosan- } \\
\text { gelatin (cartilage) and plasmid } \\
\text { GF-activated chitosan-gelatin- } \\
\text { HA (bone) hydrogels }\end{array}$ & $\begin{array}{l}\text { Plasmid TGF- } \beta 1 \\
\text { (cartilage), } \\
\text { plasmid BMP-2 } \\
\text { (bone) }\end{array}$ & Rabbit BMSCs & $\begin{array}{l}\text { Rabbit } \\
\text { osteochondral } \\
\text { defect }\end{array}$ & $\begin{array}{l}\text { Cartilage } \\
\text { Bone }\end{array}$ \\
\hline $\begin{array}{l}\text { Re'em et al. } \\
\text { 2012[61] }\end{array}$ & $\begin{array}{l}\text { Layered GF/affinity-bound } \\
\text { alginate hydrogel cartilage-bone } \\
\text { constructs }\end{array}$ & $\begin{array}{l}\text { TGF- } \beta 1 \\
\text { (cartilage), BMP-4 } \\
\text { (bone) }\end{array}$ & Human BMSCs & $\begin{array}{l}\text { Rabbit } \\
\text { osteochondral } \\
\text { defect }\end{array}$ & $\begin{array}{l}\text { Cartilage } \\
\text { Bone }\end{array}$ \\
\hline $\begin{array}{l}\text { Khanarian et } \\
\text { al. 2012a[50] }\end{array}$ & $\begin{array}{l}\text { Stratified alginate-HA composite } \\
\text { hydrogel (interface) }\end{array}$ & $\mathrm{HA}(C C)$ & $\begin{array}{l}\text { Bovine articular } \\
\text { deep zone } \\
\text { chondrocytes }\end{array}$ & - & Calcified cartilage \\
\hline $\begin{array}{l}\text { Khanarian et } \\
\text { al. 2012b[51] }\end{array}$ & $\begin{array}{l}\text { Stratified agarose-HA composite } \\
\text { hydrogel (interface) }\end{array}$ & $\mathrm{HA}(C C)$ & $\begin{array}{l}\text { Bovine articular } \\
\text { deep zone } \\
\text { chondrocytes }\end{array}$ & - & Calcified cartilage \\
\hline $\begin{array}{l}\text { Lu et al. } \\
\text { 2005[46]; } \\
\text { Jiang et al. } \\
2010[47]\end{array}$ & $\begin{array}{l}\text { Agarose hydrogel (cartilage), } \\
\text { agarose with PLGA-BG } \\
\text { microspheres (interface), and } \\
\text { PLGA-BG microspheres (bone) }\end{array}$ & $\mathrm{BG}(C C$, bone $)$ & $\begin{array}{l}\text { Human } \\
\text { osteosarcoma } \\
\text { cells, [46] } \\
\text { Human } \\
\text { osteoblast-like } \\
\text { cells,[46] } \\
\text { Bovine articular } \\
\text { full thickness } \\
\text { chondrocytes,[47] } \\
\text { Bovine } \\
\text { osteoblasts[47] }\end{array}$ & - & $\begin{array}{l}\text { Cartilage } \\
\text { Calcified cartilage } \\
\text { Bone }\end{array}$ \\
\hline $\begin{array}{l}\text { Mellor et al. } \\
2015[52]\end{array}$ & $\begin{array}{l}\text { PLA fibers (cartilage) and PLA- } \\
\beta \text {-TCP fibers (bone) }\end{array}$ & $\begin{array}{l}\text { Pre-differentiation } \\
\text { with calcium } \\
\text { gradient (cartilage } \\
\text { and bone) } \\
\beta \text {-TCP (bone) }\end{array}$ & Human ADSCs & - & $\begin{array}{l}\text { Cartilage } \\
\text { Bone }\end{array}$ \\
\hline $\begin{array}{l}\text { Huang et al. } \\
2015[57]\end{array}$ & $\begin{array}{l}\text { PLGA microspheres with TGF- } \\
\beta 3 \text { (cartilage) or BMP-4 (bone) }\end{array}$ & $\begin{array}{l}\text { TGF- } \beta 3 \text { (cartilage) } \\
\text { BMP-4 (bone) }\end{array}$ & Murine D1 MSCs & - & $\begin{array}{l}\text { Cartilage } \\
\text { Bone }\end{array}$ \\
\hline
\end{tabular}




\begin{tabular}{|c|c|c|c|c|c|}
\hline $\begin{array}{l}\text { Amadori et al. } \\
2015[87]\end{array}$ & $\begin{array}{l}\text { Freeze-dried gelatin (cartilage) } \\
\text { and HA (bone) }\end{array}$ & $\begin{array}{l}\text { Pre-differentiation } \\
\text { with chondrogenic } \\
\text { and osteogenic } \\
\text { media } \\
\text { HA (bone) }\end{array}$ & Human BMSCs & - & - \\
\hline $\begin{array}{l}\text { Kon et al. } \\
2014[88]\end{array}$ & $\begin{array}{l}\text { Biphasic coralline aragonite } \\
\text { (cartilage) with HA in cartilage } \\
\text { phase with drilled channels }\end{array}$ & $\mathrm{HA}$ & - & $\begin{array}{l}\text { Goat } \\
\text { osteochondral } \\
\text { defects }\end{array}$ & $\begin{array}{l}\text { Cartilage } \\
\text { Bone }\end{array}$ \\
\hline $\begin{array}{l}\text { Liu et al. } \\
2014[89]\end{array}$ & $\begin{array}{l}\text { PLA-co-PCL/Collagen I fibers } \\
\text { encasing collagen I/hyaluronate } \\
\text { sponge }\end{array}$ & $\beta$-TCP (bone) & Rabbit BMSCs & $\begin{array}{l}\text { Rabbit } \\
\text { osteochondral } \\
\text { defects }\end{array}$ & $\begin{array}{l}\text { Cartilage } \\
\text { Bone }\end{array}$ \\
\hline $\begin{array}{l}\text { Holmes et al. } \\
\text { 2014[45] }\end{array}$ & $\begin{array}{l}\text { 3D printed PLA with } \\
\text { homogenous or biphasic } \\
\text { (cartilage-bone) distribution of } \\
\text { network structure and pore size }\end{array}$ & - & Human BMSCs & - & Cartilage \\
\hline $\begin{array}{l}\text { Koushki et al. } \\
2015[90]\end{array}$ & $\begin{array}{l}\text { HPAM (cartilage) and HPAM-HA } \\
\text { (bone) }\end{array}$ & HA (bone) & $\begin{array}{l}\text { ADSCs and } \\
\text { articular cartilage } \\
\text { chondrocytes }\end{array}$ & - & $\begin{array}{l}\text { Cartilage } \\
\text { Bone }\end{array}$ \\
\hline \multicolumn{6}{|c|}{ Gradient Scaffold Designs } \\
\hline Study & Material and Scaffold Design & Induction Agents & Cell Source & Animal Model & Tissues Formed* \\
\hline $\begin{array}{l}\text { Aviv-Gavriel } \\
\text { et al. } \\
2013[53]\end{array}$ & $\begin{array}{l}\text { Gelatin hydrogel cartilage-bone } \\
\text { constructs with CaP gradient }\end{array}$ & $\mathrm{CaP}(C C$, bone $)$ & - & - & - \\
\hline $\begin{array}{l}\text { Harley et al. } \\
\text { 2010[54]; } \\
\text { Getgood et } \\
\text { al. 2012[55] }\end{array}$ & $\begin{array}{l}\text { Porous collagen II-GAG } \\
\text { construct (cartilage) with } \\
\text { gradient to collagen I-GAG-CaP } \\
\text { (bone) }\end{array}$ & $\mathrm{CaP}(C C$, bone $)$ & - & $\begin{array}{l}\text { Caprine } \\
\text { osteochondral } \\
\text { defect[55] }\end{array}$ & Cartilage \\
\hline $\begin{array}{l}\text { Erisken et al. } \\
2011[60]\end{array}$ & $\begin{array}{l}\text { PCL-insulin fibers (cartilage) } \\
\text { with gradient to PCL- } \beta \text {-GP fibers }\end{array}$ & $\begin{array}{l}\text { Insulin (cartilage), } \\
\beta-G P(C C, \text { bone) }\end{array}$ & Human ADSCs & - & $\begin{array}{l}\text { Cartilage } \\
\text { Bone }\end{array}$ \\
\hline
\end{tabular}

